CLINICAL STUDY

\title{
Association of a MTNR $1 B$ gene variant with fasting glucose and HOMA-B in children and adolescents with high BMI-SDS
}

\author{
Christina Holzapfel $^{1,2}$, Monika Siegrist ${ }^{3}$, Melanie Rank ${ }^{3}$, Helmut Langhof ${ }^{4}$, Harald Grallert ${ }^{2,5}$, Jens Baumert ${ }^{2}$, \\ Corinna Irimie $^{4}$, Norman Klopp ${ }^{2}$, Bernd Wolfarth ${ }^{3}$, Thomas Illig ${ }^{2}$, Hans Hauner ${ }^{1}$ and Martin Halle ${ }^{3}$ \\ ${ }^{1}$ Else Kroener-Fresenius-Centre for Nutritional Medicine, University Hospital "Klinikum rechts der Isar", Universität München, Technische Ismaninger \\ Strasse 22, Building 521, 81675 Munich, Germany, ${ }^{2}$ Institute of Epidemiology, Helmholtz Zentrum München, German Research Centre for \\ Environmental Health, Neuherberg, Germany, ${ }^{3}$ Preventive and Rehabilitative Sports Medicine, Technische Universität München, Munich, Germany, \\ ${ }^{4}$ Rehabilitation Hospital Schönsicht, Berchtesgaden, Germany and ${ }^{5}$ Institute of Medical Information Processing, Biometry and Epidemiology, Chair of \\ Epidemiology, Ludwig-Maximilians-University, \\ Munich, Germany
}

(Correspondence should be addressed to C Holzapfel at Else Kroener-Fresenius-Centre for Nutritional Medicine; Email: christina.holzapfel@wzw.tum.de)

\begin{abstract}
Context: Genome-wide association studies have shown that the melatonin receptor 1B (MTNR1B) gene locus is strongly associated with fasting glucose and $\beta$-cell function. However, data are rather limited to the adult population and normal-weight children. So far, little is known whether similar associations are present in overweight and obese children and adolescents.

Objective: The aim is to investigate an MTNR1B polymorphism in a sample of 310 overweight and obese children and adolescents (mean body mass index standard deviation score (BMI-SDS)): 2.74 $( \pm 0.55)$, mean age: $14( \pm 2)$ years), who participated in a short-term weight-loss program based on energy reduction, physical activity, and behavior therapy.

Methods: We investigated an association between genotype and fasting glucose, fasting insulin, homeostasis model assessment of insulin resistance (HOMA-IR) and of $\beta$-cell function (HOMA-B), and anthropometric parameters and their change during intervention.

Results: The minor $\mathrm{G}$ allele of polymorphism rs10830963 was significantly associated with increased fasting glucose $(0.205 \mathrm{mmol} / \mathrm{l}, P<0.0001)$ and decreased HOMA-B $(-0.353, P<0.0001)$. Categorizing the sample into BMI-SDS groups, these significant associations were abolished in children with BMI-SDS below 2.5 but remained in those with higher BMI-SDS values with stronger $\beta$-estimates. The $P$ value for the genotype $\times$ BMI-SDS category interaction was 0.012 for fasting glucose and 0.083 for HOMA-B. There was no significant association between genotype and anthropometric parameters and their change during intervention.

Conclusions: This is the first single study, replicating the association between the MTNR1B locus and diabetes-related traits in overweight and obese children and adolescents. The effect sizes in children and adolescents seem to be stronger than in adults and differed among BMI-SDS categories.
\end{abstract}

European Journal of Endocrinology $164205-212$

\section{Introduction}

Type 2 diabetes is a complex disease in which blood glucose levels are elevated due to $\beta$-cell dysfunction and/or insulin resistance. The recent genome-wide association studies have identified new genetic loci associated with the risk of type 2 diabetes and glucose levels $(1,2)$.

A meta-analysis of 21 genome-wide association studies has reported that in the Framingham cohort about $10 \%$ of the inherited variation in fasting glucose levels is explained by 14 gene loci (1). Up to now, the glucose-6-phosphatase (G6PC2) gene and the melatonin receptor 1B (MTNR1B) gene are the loci with the strongest association with fasting glucose $(1,3-7)$, whereas the initial genome-wide association studies reported the strongest association for the MTNR1B locus (5-7). Prokopenko et al. (6) published an increased fasting glucose level of $0.07 \mathrm{mmol} / \mathrm{l}$ per minor $\mathrm{G}$ allele in adults. This effect size was also observed in healthy normal-weight children (8). An analysis of 1309 European children has shown that the observations are consistent with that seen in adults, but the effect size estimate in children was smaller (1). In the normal-weight adolescents of the Northern Finland Birth Cohort 86 aged 16 years, an association between MTNR1B locus and fasting glucose has been replicated (5). In lean healthy adolescents from China, a 
borderline significant association with fasting glucose was reported for the MTNR1B locus (9). Another MTNR1B polymorphism (rs8192552) with an amino acid exchange was associated with increased body mass index (BMI), waist circumference, and obesity risk in Danish and French adults (10).

Melatonin receptors are members of the family of G-protein-coupled receptors and the MTNR1B gene was predicted to encode one of the melatonin receptors, which was originally reported to be expressed in human retina and brain (11). It has recently been shown that the gene is also transcribed in human pancreatic islet cells $(7,12)$. Melatonin has an inhibitory effect on insulin secretion in clonal $\beta$-cells (7, 12-14), thereby explaining the association between the MTNR1B locus and fasting glucose as well as type 2 diabetes $(15,16)$.

Given the known link between melatonin and insulin as well as the recent findings between polymorphism rs10830963 and diabetes-related parameters in adults and the scarce knowledge of this association in overweight and obese children and adolescents, we investigated this polymorphism for the association with fasting glucose, fasting insulin, homeostasis model assessment of insulin resistance (HOMA-IR), and of $\beta$-cell function (HOMA-B) in a sample of 310 overweight and obese children and adolescents participating in a standardized weight-loss program. Analyses were extended to anthropometric parameters (weight, body mass index standard deviation score (BMI-SDS), waist circumference). Furthermore, using data from the well-standardized weight-loss program, we studied whether the risk allele $G$ is associated with the change of anthropometric parameters during intervention.

\section{Subjects and methods}

\section{Study sample}

Overweight and obese children and adolescents participating in the 'Long-term effects of a lifestyle intervention in obesity and genetic influence in children (LOGIC)' study were recruited between January 2006 and June 2008. The children had no endocrine or syndromal disorder and participated in a standardized in-patient lifestyle intervention program for weight loss at the Rehabilitation Hospital Schönsicht in Berchtesgaden (Germany). Genotyping was performed in 310 children and adolescents (123 boys/187 girls) aged 8-19 years. All children were Caucasian and written informed consent for the genetic analysis was obtained for every participant. The study was approved by the ethics committee of the Faculty of Medicine of the Technische Universität München. The 4 to 6 week intervention program consisted of a moderate energy reduction of about $500 \mathrm{kcal} /$ day, physical activities such as swimming and walking (11 h/week), and behavior therapy. The duration of the lifestyle intervention was documented for every subject.

\section{Assessment of demographic and clinical characteristics}

Standardized questionnaires were used to obtain demographic variables. All clinical examinations were conducted by trained medical staff. Body weight was measured in underwear to the nearest $0.1 \mathrm{~kg}$ (Tanita BC-420 P MA Profi, Tanita Europe B V, Hoofddorp, The Netherlands) and height to the nearest $0.5 \mathrm{~cm}$ by a rigid stadiometer. BMI-SDS was calculated using an established equation $(17,18)$. Waist circumference $(\mathrm{cm})$ was measured on the midway between the lowest rib margin and the superior border of the iliacal crest using a nonstretch measuring tape to the nearest $0.5 \mathrm{~cm}$. After an overnight fast, blood was taken and glucose and insulin levels were measured after admission. Plasma glucose was measured by the hexokinase method (COBAS INTEGRA 800, Roche Diagnostics $\mathrm{GmbH}$ ) and insulin by an ELISA (Mercodia, Uppsala, Sweden). HOMA-IR as a measure of insulin sensitivity and HOMA-B as an index of $\beta$-cell function were calculated according to Matthews et al. (19). These indexes have been validated in healthy children (20).

\section{Genotyping}

The top signal (rs10830963) within the MTNR1B gene reported by Prokopenko et al. (6) was selected for genotyping. The MTNR1B gene is localized at chromosome 11 and the minor $G$ allele of the intronic polymorphism rs10830963 has a frequency of $30 \%$ (HapMap, dbSNP b126). Samples were genotyped with the MassARRAY system using the iPLEX Gold Chemistry (Sequenom, San Diego, CA, USA). The samples were analyzed in a matrix-assisted laser desorption ionization time of flight mass spectrometer (MALDI TOF MS, Bruker Daltonik, Leipzig, Germany). $\chi^{2}$ test was used to test for deviation from the Hardy-Weinberg equilibrium (HWE). The single nucleotide polymorphism (SNP) rs10830963 fulfilled HWE $(P>0.05)$, and the genotyping success rate was $99 \%$. The minor allele frequency in our sample was $28 \%$, which is comparable to the literature (6). Owing to the gender test with glycogenin 2 (GYG2) gene and the double-genotyping of samples, high genotyping quality was reached.

\section{Statistical analysis}

Means and S.D. or medians and inter quartile ranges (IQR) were used for descriptive statistics at study entry, and after 4 and 6 weeks of intervention. Fasting insulin, HOMA-IR, and HOMA-B were approximately log-normal distributed and therefore log-transformed 
(natural log) for the analyses. For HOMA-B, negative values were excluded. Associations between the polymorphism and fasting glucose, fasting insulin, HOMA-IR, and HOMA-B at study entry were analyzed by linear regression.

In a secondary analysis, the genotype-glucose and the genotype-HOMA-B association were studied for different BMI-SDS groups (A) according to sample size $(x<2.5$; $2.5 \leq x<3.0 ; x \geq 3.0)$ and (B) dichotomized according to the mean $(x<2.74 ; x \geq 2.74)$. SNP-parameter interaction analyses were performed by including additionally the respective parameter and an interaction term, SNP $\times$ parameter, in the regression equation. The interaction terms SNP $\times$ BMI-SDS (continuous trait), SNP $\times$ BMI-SDS category, and SNP $\times$ gender were calculated for fasting glucose and HOMA-B.

To study the association between genotype and anthropometric parameters and their changes during intervention, linear regression was performed for weight, BMI-SDS, and waist circumference.

All linear analyses were in the first model, adjusted for sex and age as well as in a second model for BMI-SDS. In all linear models, an additive genetic effect was assumed. In a sensitivity analysis, values below $1 \%$ and above 99\% percentile and for HOMA-B values below $10 \%$ and $90 \%$ percentile were excluded.

Statistical analyses were performed using SAS Version 9.1 (SAS Institute, Cary, NC, USA).

\section{Results}

\section{Description of study sample}

Main characteristics of the study sample are shown in Table 1. A proportion of $60 \%$ of the participants were girls. Means (s.D.) or medians (IQR) of fasting glucose, fasting insulin, HOMA-IR, and HOMA-B as well as of anthropometric parameters according to genotype are shown in Table 2. BMI-SDS itself was significantly correlated with fasting glucose, fasting insulin, HOMA-IR, and HOMA-B (Pearson correlation coefficient: 0.15, $0.43,0.42$, or 0.18 respectively).

\section{Diabetes-related traits}

Polymorphism rs10830963 was significantly associated with fasting glucose levels and HOMA-B (Table 2). There was an increase in fasting glucose per minor $\mathrm{G}$ allele by $0.205 \mathrm{mmol} / \mathrm{l}\left(P=1.17 \times 10^{-7}\right)$. Additional adjustment for BMI-SDS did not change the association $\left(0.201 \mathrm{mmol} / \mathrm{l}, P=1.41 \times 10^{-7}\right)$. Moreover, the minor $\mathrm{G}$ allele showed a significant association with HOMA-B independent of BMI-SDS (not BMI-SDS adjusted: $-0.353, P=1.58 \times 10^{-6}$; BMI-SDS adjusted: $\left.-0.353, P=1.26 \times 10^{-6}\right)$. For fasting insulin and HOMA-IR, no significant associations were observed $(P>0.05 ;$ Table 2). For the sensitivity analysis, we
Table 1 Characteristics of the study sample at different time points. Means (S.D.) are shown for normally distributed parameters. Anthropometric parameters are shown at different time points (at study entry, after 4 and 6 weeks of intervention). For HOMA-B, negative values were excluded.

\begin{tabular}{lcc}
\hline Parameter & $\boldsymbol{n}$ (boys/girls) & $\begin{array}{c}\text { Mean (s.D.) or } \\
\text { median }^{\mathrm{a}}(\mathrm{IQR})\end{array}$ \\
\hline $\begin{array}{l}\text { Age (years) } \\
\text { Height (cm) }\end{array}$ & $310(123 / 187)$ & $14(2)$ \\
At study entry & $310(123 / 187)$ & $163.0(10.9)$ \\
Weight (kg) & $310(123 / 187)$ & $90.17(22.93)$ \\
BMl-SDS & $310(123 / 187)$ & $2.74(0.55)$ \\
Waist circumference (cm) & $297(121 / 176)$ & $109.30(14.58)$ \\
Fasting glucose (mmol/l) & $307(121 / 186)$ & $3.93(0.45)$ \\
Fasting insulin (mU/l) & $306(121 / 185)$ & $10.00(6.28)$ \\
HOMA-IR $^{\mathrm{a}}$ & $303(119 / 184)$ & $1.75(1.23)$ \\
HOMA-B & $258(92 / 166)$ & $415.45(416.06)$ \\
After 4 weeks of intervention & & \\
Weight loss (kg) & $297(114 / 183)$ & $8.26(2.82)$ \\
BMI-SDS loss & $297(114 / 183)$ & $0.36(0.10)$ \\
Waist circumference loss (cm) & $84(36 / 48)$ & $6.91(4.60)$ \\
After 6 weeks of intervention & & \\
Weight loss (kg) & $187(71 / 116)$ & $10.94(3.62)$ \\
BMI-SDS loss & $187(71 / 116)$ & $0.47(0.13)$ \\
Waist circumference loss (cm) & $128(55 / 73)$ & $7.68(4.81)$ \\
\hline
\end{tabular}

${ }^{a}$ Medians (inter quartile ranges, IQR) are shown for the not normally distributed parameters (fasting insulin, HOMA-IR, and HOMA-B respectively).

excluded values below the $1 \%$ percentile and above the $99 \%$ percentile of the respective distribution and repeated the regression analyses. No major differences to the analyses in the full sample were observed. For HOMA-B, values below the $10 \%$ and above the $90 \%$ percentile were excluded (median (IQR): 413.86 (297.59), $n=207)$. Linear regression showed similar results $\left(-0.209, P=8.65 \times 10^{-6}\right)$.

\section{Diabetes-related traits according to BMI-SDS}

To assess whether the genotype-glucose and the genotype-HOMA-B associations were modified by BMI-SDS, we performed an interaction analysis (Table 3).

The interaction term SNP $\times$ BMI-SDS (continuous) was not statistically significant for fasting glucose or HOMA-B $(P=0.274$ and 0.068$)$. In the analysis of BMI-SDS categories, according to sample size (Table 3A), the interaction term SNP $\times$ BMI-SDS category was statistically significant for fasting glucose $(P=0.012)$ and not significant for HOMA-B $(P=0.083)$. After exclusion of glucose values below the $1 \%$ and above the $99 \%$ percentile, the interaction term remained significant $(P=0.014)$ and of HOMA-B values below the $10 \%$ and above the $90 \%$ percentile, the interaction term became borderline significant $(P=0.046)$. In the analysis of dichotomized BMI-SDS categories, neither for fasting glucose nor for HOMA-B the interaction term was significant (Table 3B). The respective associations stratified by different BMI-SDS groups are shown in Table $3 \mathrm{~A}$ and B. In subjects with a BMI-SDS $<2.5$, the association between rs10830963 and fasting glucose as 
Table 2 Association between rs10830963 (MTNR1B) and fasting glucose, fasting insulin, HOMA-IR and HOMA-B as well as anthropometric traits. Genotype-specific means (S.D.) are shown for normally distributed parameters. $\beta$-estimates, S.E.M. and $P$ values are given for the regression analysis. For regression analysis fasting insulin, HOMA-IR, and HOMA-B were log-transformed. Adjustments for age and sex were performed in all analyses. For HOMA-B, negative values were excluded.

\begin{tabular}{|c|c|c|c|c|c|c|c|c|}
\hline \multirow[b]{2}{*}{ Parameter } & \multicolumn{2}{|r|}{ CC } & \multicolumn{2}{|r|}{ CG } & \multicolumn{2}{|r|}{ GG } & \multirow[b]{2}{*}{$\begin{array}{l}\beta \text {-Estimate } \\
\text { (S.E.M.) }\end{array}$} & \multirow[b]{2}{*}{$P$ value } \\
\hline & $n$ & $\begin{array}{l}\text { Mean (S.D.) or } \\
\text { median }^{\mathrm{a}} \text { (IQR) }\end{array}$ & $n$ & $\begin{array}{l}\text { Mean (S.D.) or } \\
\text { median }^{\mathrm{a}} \text { (IQR) }\end{array}$ & $n$ & $\begin{array}{l}\text { Mean (S.D.) or } \\
\text { median }^{\mathrm{a}} \text { (IQR) }\end{array}$ & & \\
\hline \multicolumn{9}{|l|}{ At study entry } \\
\hline Weight $(\mathrm{kg})$ & 162 & $87.90(23.94)$ & 121 & $91.60(21.04)$ & 27 & $97.45(23.75)$ & $0.601(1.579)$ & 0.704 \\
\hline BMI-SDS & 162 & $2.71(0.55)$ & 121 & $2.73(0.53)$ & 27 & $2.91(0.63)$ & $0.028(0.047)$ & 0.544 \\
\hline Waist circumference $(\mathrm{cm})$ & 158 & $107.95(15.19)$ & 114 & $110.27(13.53)$ & 25 & $113.41(14.69)$ & $0.668(1.151)$ & 0.562 \\
\hline Fasting glucose $(\mathrm{mmol} / \mathrm{l})$ & 160 & $3.84(0.41)$ & 120 & $3.97(0.43)$ & 27 & $4.28(0.53)$ & $0.205(0.038)$ & $1.17 \times 10^{-7}$ \\
\hline Fasting insulin $\left(\mathrm{mU} / \mathrm{l}^{\mathrm{a}}\right.$ & 161 & $10.10(6.01)$ & 118 & $9.65(6.59)$ & 27 & $12.00(6.97)$ & $0.007(0.046)$ & 0.878 \\
\hline HOMA-IR ${ }^{\mathrm{a}}$ & 159 & $1.76(1.20)$ & 117 & $1.62(1.23)$ & 27 & $2.22(1.34)$ & $0.060(0.052)$ & 0.243 \\
\hline HOMA-B $^{\mathrm{a}}$ & 131 & $531.22(556.10)$ & 101 & $395.01(370.36)$ & 26 & $320.18(124.38)$ & $-0.353(0.072)$ & $1.58 \times 10^{-6}$ \\
\hline \multicolumn{9}{|l|}{ After intervention } \\
\hline Weight loss $(\mathrm{kg})$ after 4 weeks & 154 & $8.11(2.82)$ & 116 & $8.52(2.73)$ & 27 & $8.01(3.19)$ & $-0.144(0.212)$ & 0.498 \\
\hline Weight loss (kg) after 6 weeks & 98 & $10.61(3.65)$ & 74 & $11.28(3.46)$ & 15 & $11.39(4.25)$ & $0.277(0.355)$ & 0.436 \\
\hline BMI-SDS loss after 4 weeks & 154 & $0.36(0.11)$ & 116 & $0.36(0.10)$ & 27 & $0.32(0.10)$ & $-0.013(0.009)$ & 0.163 \\
\hline BMI-SDS loss after 6 weeks & 98 & $0.46(0.13)$ & 74 & $0.49(0.14)$ & 15 & $0.44(0.12)$ & $0.002(0.015)$ & 0.894 \\
\hline $\begin{array}{l}\text { Waist circumference loss }(\mathrm{cm}) \\
\text { after } 4 \text { weeks }\end{array}$ & 43 & $6.60(3.64)$ & 29 & $6.85(5.29)$ & 12 & $8.16(5.97)$ & $0.728(0.728)$ & 0.320 \\
\hline $\begin{array}{l}\text { Waist circumference loss }(\mathrm{cm}) \\
\text { after } 6 \text { weeks }\end{array}$ & 76 & $7.05(4.51)$ & 46 & $8.76(5.33)$ & 6 & $7.37(2.97)$ & $0.904(0.731)$ & 0.218 \\
\hline
\end{tabular}

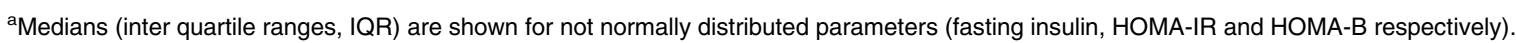

well as HOMA-B was abolished $(P>0.05$; Table 3A). However, compared to the association between fasting glucose and HOMA-B in the whole sample, in obese subjects (BMI-SDS: $2.5 \leq x<3.0$ ) the $\beta$-estimates for fasting glucose and HOMA-B were moderately higher (glucose: $0.239 \mathrm{mmol} / \mathrm{l}, P=6.37 \times 10^{-5}$; HOMA-B: $\left.-0.377, P=1.90 \times 10^{-3}\right)$. In the very obese children and adolescents with a BMI-SDS $\geq 3.0$, the $\beta$-estimates for fasting glucose and HOMA-B were much higher (glucose: $0.299 \mathrm{mmol} / \mathrm{l}, P=6.97 \times 10^{-5}$; HOMA-B: $-0.537, P=2.39 \times 10^{-5}$ ) (Table $3 \mathrm{~A}$ ) compared with the whole study sample (Table 2). Analyzing the dichotomized BMI-SDS categories confirmed the results that the effect size is bigger in the higher BMI-SDS category, whereas the association was significant for both the BMI-SDS groups (Table 3B). Furthermore, the $\mathrm{SNP} \times$ gender interaction term was not significant (glucose: $P=0.150$; HOMA-B: $P=0.572$ ).

\section{Anthropometric parameters (weight, BMI-SDS, waist circumference)}

There was no significant association between rs10830963 and weight $(0.601 \mathrm{~kg}, P=0.704)$, BMISDS $(0.028, P=0.544)$, or waist circumference

Table 3 Association between rs10830963 (MTNR1B) and fasting glucose and HOMA-B in different BMI-SDS categories. $\beta$-estimates, S.E.M. and $P$ values are shown for the analyzed parameters in different BMI-SDS-categories. $P$ values for the interaction term of SNP $\times$ BMI-SDS category are given. Adjustment for age and sex were performed in all analyses.

\begin{tabular}{|c|c|c|c|c|c|c|}
\hline \multirow[b]{2}{*}{ BMI-SDS categories } & \multirow[b]{2}{*}{$\boldsymbol{n}$ (boys/girls) } & \multirow[b]{2}{*}{$\boldsymbol{\beta}$-estimate (S.E.M.) } & \multirow[b]{2}{*}{$P$ value } & \multicolumn{3}{|c|}{ Interaction SNP $\times$ BMI-SDS category } \\
\hline & & & & $\beta$-estimate (S.E.M.) & $P$ value & Global $P$ value \\
\hline \multicolumn{7}{|c|}{ A) According to sample size } \\
\hline$<2.5$ & $108(49 / 59)$ & $0.035(0.064)$ & 0.589 & - & - & \multirow{3}{*}{0.012} \\
\hline $2.5 \leq \times<3.0$ & $103(47 / 56)$ & $0.239(0.057)$ & $6.37 \times 10^{-5}$ & $0.209(0.093)$ & 0.026 & \\
\hline $\begin{array}{l}\geq 3.0 \\
\text { HOMA-B }\end{array}$ & $96(25 / 71)$ & $0.299(0.072)$ & $6.97 \times 10^{-5}$ & $0.265(0.091)$ & $3.92 \times 10^{-3}$ & \\
\hline$<2.5$ & $85(35 / 50)$ & $-0.189(0.133)$ & 0.159 & - & - & \multirow{3}{*}{0.083} \\
\hline $2.5 \leq \times<3.0$ & $87(35 / 52)$ & $-0.377(0.118)$ & $1.90 \times 10^{-3}$ & $-0.144(0.178)$ & 0.419 & \\
\hline$\geq 3.0$ & $86(22 / 64)$ & $-0.537(0.120)$ & $2.39 \times 10^{-5}$ & $-0.380(0.174)$ & 0.030 & \\
\hline \multicolumn{7}{|c|}{ B) Dichotomized ( $</ \geq$ mean) } \\
\hline \multicolumn{7}{|c|}{ Fasting glucose $(\mathrm{mmol} / \mathrm{l})$} \\
\hline$<2.74$ & $168(79 / 89)$ & $0.141(0.047)$ & $2.93 \times 10^{-3}$ & \multirow[t]{3}{*}{$0.120(0.074)$} & \multirow[t]{3}{*}{0.106} & \multirow[t]{3}{*}{-} \\
\hline$\geq 2.74$ & $139(42 / 97)$ & $0.278(0.060)$ & $7.36 \times 10^{-6}$ & & & \\
\hline \multicolumn{4}{|l|}{ HOMA-B } & & & \\
\hline$<2.74$ & $140(61 / 79)$ & $-0.300(0.096)$ & $2.09 \times 10^{-3}$ & \multirow[t]{2}{*}{$-0.148(0.139)$} & \multirow[t]{2}{*}{0.289} & \multirow{2}{*}{-} \\
\hline$\geq 2.74$ & $118(31 / 87)$ & $-0.428(0.104)$ & $7.52 \times 10^{-5}$ & & & \\
\hline
\end{tabular}


$(0.668 \mathrm{~cm}, P=0.562)$ at study entry respectively (Table 2). Furthermore, no significant result was observed for BMI-SDS reduction after 4 and 6 weeks of intervention ( $-0.013, P=0.163 ; 0.002, P=0.894)$ respectively. In addition, for weight and waist circumference loss no significant associations were observed (Table 2).

\section{Discussion}

This is the first independent study investigating the association of rs10830963 with traits related to glucose metabolism in overweight and obese children and adolescents. We observed a significant association with fasting glucose and HOMA-B, which was dependent on the obesity status, and no association with fasting insulin and HOMA-IR. However, no association could be detected between the SNP and weight, BMISDS, or waist circumference before and after the lifestyle intervention.

Compared to the effect size of $0.07 \mathrm{mmol} / \mathrm{l}$ (glucose) per minor allele in adults (6) and healthy children (8), the $\beta$-estimate observed in overweight and obese children and adolescents was higher $(0.205 \mathrm{mmol} / \mathrm{l})$, especially for the extremely obese (BMI-SDS $\geq 3.0$ ) children $(0.299 \mathrm{mmol} / \mathrm{l})$. The interaction between SNP $\times$ BMI-SDS category supports the finding that the association might be related to obesity status.

One could argue that the lack of an association in children of the BMI-SDS-group $<2.5$ is due to a lack of statistical power, because Kelliny et al. (8) observed a strong association between MTNR $1 B$ and fasting glucose in normal-weight children. Owing to the fact that in approach A (Table 3A) of BMI-SDS categorization, the sample size is the same in all the three groups, the finding might not be due to lack of statistical power. In the dichotomized BMI-SDS analysis, the association with fasting glucose in the lower BMI-SDS group $(<2.74)$ was significant. This difference might be due to the very small number of children homozygous for the minor allele.

Despite the very small effect in huge population-based studies, the early effect in life of the MTNR1B locus seen in our special cohort may have the potential for an early identification of obese children at high risk of diabetes. Given the fact that almost no investigation on diabetes in children has been made and that the early identification of children and adolescents at risk of type 2 diabetes might be a big challenge, the locus investigated in this study might be used together with some other loci for diagnostic purposes in the future.

Recent data indicate that melatonin, the ligand to MTNR1B, has an inhibitory effect on insulin secretion (7, 12-14). Therefore, our data replicate that children carrying the risk allele might be more sensitive to this inhibitory effect than noncarriers. Our results on the relationship between the MTNR1B SNP and increased fasting glucose as well as decreased HOMA-B are in agreement with this hypothesis. Risk allele carriers were also shown to have increased mRNA levels of MTNR 1B in $\beta$-cells (7), which may lead to a decreased insulin secretion resulting in elevated fasting glucose levels (16).

Our non-significant results for fasting insulin and HOMA-IR are in line with the results from recent publications $(5,6)$. In a recent study, the MTNR $1 B$ locus showed an association with lower insulinogenic index, but no association with insulin sensitivity (21).

In contrast to published data on an association between an MTNR1B variant (rs8192552) causing an amino acid exchange and obesity risk, BMI, and waist circumference, we found no association between rs10830963 and weight, BMI-SDS, and waist circumference or their changes during intervention (10). However, this finding might be due to the fact that rs10830963 is not in linkage disequilibrium with the polymorphism rs8192552 and also due to insufficient power of our ongoing weight-loss study.

Given the different effect size in adults and overweight and obese children and adolescents, young subjects as well as special groups may be particularly suitable for identifying new genetic variants related to glucose metabolism that has not yet been detected before in the adult population. This may also be of interest as other genes may be important before and after puberty. In a recently published genome-wide analysis by Scherag et al. (22), two new loci for obesity risk were detected in children and adolescents. The association between tankyrase, TRF1-interacting ankyrin-related ADPribose polymerase, and methionine sulfoxide reductase A (TNKS/MSRA) gene locus and obesity was limited to children and adolescents, whereas an association between this locus and waist circumference in adults was already shown (23).

The strength of our analyses is that we have included well-characterized overweight and obese children and adolescents participating in a prospective lifestyle intervention program and that we have data before and after weight loss. Thus, our analysis represents a clear approach to replicate the recent findings of Prokopenko et al. (6). Although the sample size of our study is rather limited, it seems to be sufficient, taking into account the effect size for fasting glucose and HOMA-B observed in our analysis. Owing to the small sample size our sub-analysis in the different BMI-SDS groups is risky and requires replication of the findings in a much larger study sample of overweight and obese children. The significant interaction term could be a false-positive finding. Furthermore, the analysis of a control group of normal-weight children would be interesting.

In conclusion, our data provide evidence that the rs10830963 polymorphism is associated with fasting glucose levels and HOMA-B in overweight and obese children and adolescents, especially in the higher BMI-SDS groups. The effect size for glucose levels per 
minor allele seems to be higher than that reported for normal-weight children and adults. There was no association with anthropometric traits such as weight, BMI-SDS, or waist circumference.

\section{Declaration of interest}

The authors declare that there is no conflict of interest that could be perceived as prejudicing the impartiality of the research reported.

\section{Funding}

This research did not receive any specific grant from any funding agency in the public, commercial or not-for-profit sector.

\section{Acknowledgements}

We thank the staff of the Rehabilitation Hospital Schönsicht, Berchtesgaden, who was involved in the collection of samples and data. Furthermore, we are grateful to Franziska Scharl and Jana Günther (Helmholtz Zentrum München) for assistance in genotyping and to Gerlinde Trischler (University of Ulm) for assistance in determining the biochemical parameters. Finally, we thank all children and their parents participating in the study.

\section{References}

1 Dupuis J, Langenberg C, Prokopenko I, Saxena R, Soranzo N, Jackson AU, Wheeler E, Glazer NL, Bouatia-Naji N, Gloyn AL, Lindgren CM, Magi R, Morris AP, Randall J, Johnson T, Elliott P, Rybin D, Thorleifsson G, Steinthorsdottir V, Henneman P, Grallert H, Dehghan A, Hottenga JJ, Franklin CS, Navarro P, Song K, Goel A, Perry JR, Egan JM, Lajunen T, Grarup N, Sparso T, Doney A, Voight BF, Stringham HM, Li M, Kanoni S, Shrader P, Cavalcanti-Proenca C, Kumari M, Oi L, Timpson NJ, Gieger C, Zabena C, Rocheleau G, Ingelsson E, An P, O'Connell J, Luan J, Elliott A, McCarroll SA, Payne F, Roccasecca RM, Pattou F, Sethupathy P, Ardlie K, Ariyurek Y, Balkau B, Barter P, Beilby JP, Ben Shlomo Y, Benediktsson R, Bennett AJ, Bergmann S, Bochud M, Boerwinkle E, Bonnefond A, Bonnycastle LL, BorchJohnsen K, Bottcher Y, Brunner E, Bumpstead SJ, Charpentier G, Chen YD, Chines P, Clarke R, Coin LJ, Cooper MN, Cornelis M, Crawford G, Crisponi L, Day IN, de Geus EJ, Delplanque J, Dina C, Erdos MR, Fedson AC, Fischer-Rosinsky A, Forouhi NG, Fox CS, Frants R, Franzosi MG, Galan P, Goodarzi MO, Graessler J, Groves CJ, Grundy S, Gwilliam R, Gyllensten U, Hadjadj S, Hallmans G, Hammond N, Han X, Hartikainen AL, Hassanali N, Hayward C, Heath SC, Hercberg S, Herder C, Hicks AA, Hillman DR, Hingorani AD, Hofman A, Hui J, Hung J, Isomaa B, Johnson PR, Jorgensen T, Jula A, Kaakinen M, Kaprio J, Kesaniemi YA, Kivimaki M, Knight B, Koskinen S, Kovacs P, Kyvik KO, Lathrop GM, Lawlor DA, Le Bacquer O, Lecoeur C, Li Y, Lyssenko V, Mahley R, Mangino M, Manning AK, MartinezLarrad MT, McAteer JB, McCulloch LJ, McPherson R, Meisinger C, Melzer D, Meyre D, Mitchell BD, Morken MA, Mukherjee S, Naitza S, Narisu N, Neville MJ, Oostra BA, Orru M, Pakyz R, Palmer CN, Paolisso G, Pattaro C, Pearson D, Peden JF, Pedersen NL, Perola M, Pfeiffer AF, Pichler I, Polasek O, Posthuma D, Potter SC, Pouta A, Province MA, Psaty BM, Rathmann W, Rayner NW, Rice K, Ripatti S, Rivadeneira F, Roden M, Rolandsson O, Sandbaek A, Sandhu M, Sanna S, Sayer AA, Scheet P, Scott LJ, Seedorf U, Sharp SJ, Shields B, Sigurethsson G, Sijbrands EJ, Silveira A, Simpson L, Singleton A, Smith NL, Sovio U, Swift A, Syddall H, Syvanen AC, Tanaka T, Thorand B, Tichet J, Tonjes A, Tuomi T, Uitterlinden AG, van Dijk KW, van Hoek M, Varma D, Visvikis-Siest S, Vitart V,
Vogelzangs N, Waeber G, Wagner PJ, Walley A, Walters GB, Ward KL, Watkins H, Weedon MN, Wild SH, Willemsen G, Witteman JC, Yarnell JW, Zeggini E, Zelenika D, Zethelius B, Zhai G, Zhao JH, Zillikens MC, Borecki IB, Loos RJ, Meneton P, Magnusson PK, Nathan DM, Williams GH, Hattersley AT, Silander K, Salomaa V, Smith GD, Bornstein SR, Schwarz P, Spranger J, Karpe F, Shuldiner AR, Cooper C, Dedoussis GV, Serrano-Rios M, Morris AD, Lind L, Palmer LJ, Hu FB, Franks PW, Ebrahim S, Marmot M, Kao WH, Pankow JS, Sampson MJ, Kuusisto J, Laakso M, Hansen T, Pedersen O \& Pramstaller PP. New genetic loci implicated in fasting glucose homeostasis and their impact on type 2 diabetes risk. Nature Genetics 201042 105-116. (doi:10.1038/ng.520)

2 Voight BF, Scott LJ, Steinthorsdottir V, Morris AP, Dina C, Welch RP, Zeggini E, Huth C, Aulchenko YS, Thorleifsson G, McCulloch LJ, Ferreira T, Grallert H, Amin N, Wu G, Willer CJ, Raychaudhuri S, McCarroll SA, Langenberg C, Hofmann OM, Dupuis J, Qi L, Segre AV, van Hoek M, Navarro P, Ardlie K, Balkau B, Benediktsson R, Bennett AJ, Blagieva R, Boerwinkle E, Bonnycastle LL, Bengtsson BK, Bravenboer B, Bumpstead S, Burtt NP, Charpentier G, Chines PS, Cornelis M, Couper DJ, Crawford G, Doney AS, Elliott KS, Elliott AL, Erdos MR, Fox CS, Franklin CS, Ganser M, Gieger C, Grarup N, Green T, Griffin S, Groves CJ, Guiducci C, Hadjadj S, Hassanali N, Herder C, Isomaa B, Jackson AU, Johnson PR, Jorgensen T, Kao WH, Klopp N, Kong A, Kraft P, Kuusisto J, Lauritzen T, Li M, Lieverse A, Lindgren CM, Lyssenko V, Marre M, Meitinger T, Midthjell K, Morken MA, Narisu N, Nilsson P, Owen KR, Payne F, Perry JR, Petersen AK, Platou C, Proenca C, Prokopenko I, Rathmann W, Rayner NW, Robertson NR, Rocheleau G, Roden M, Sampson MJ, Saxena R, Shields BM, Shrader P, Sigurdsson G, Sparso T, Strassburger K, Stringham HM, Sun Q, Swift AJ, Thorand B, Tichet J, Tuomi T, van Dam RM, van Haeften TW, van Herpt T, Vliet-Ostaptchouk JV, Walters GB, Weedon MN, Wijmenga C, Witteman J, Bergman RN, Cauchi S, Collins FS, Gloyn AL, Gyllensten U, Hansen T, Hide WA, Hitman GA, Hofman A, Hunter DJ, Hveem K, Laakso M, Mohlke KL, Morris AD, Palmer CN, Pramstaller PP, Rudan I, Sijbrands E, Stein LD, Tuomilehto J, Uitterlinden A, Walker M, Wareham NJ, Watanabe RM, Abecasis GR, Boehm BO, Campbell H, Daly MJ, Hattersley AT, Hu FB, Meigs JB, Pankow JS, Pedersen O, Wichmann HE, Barroso I, Florez JC, Frayling TM, Groop L, Sladek R, Thorsteinsdottir U, Wilson JF, Illig T, Froguel P, Van Duijn CM, Stefansson K, Altshuler D, Boehnke M \& McCarthy MI. Twelve type 2 diabetes susceptibility loci identified through largescale association analysis. Nature Genetics 201042 579-589. (doi:10.1038/ng.609)

3 Chen WM, Erdos MR, Jackson AU, Saxena R, Sanna S, Silver KD, Timpson NJ, Hansen T, Orru M, Grazia PM, Bonnycastle LL, Willer CJ, Lyssenko V, Shen H, Kuusisto J, Ebrahim S, Sestu N, Duren WL, Spada MC, Stringham HM, Scott LJ, Olla N, Swift AJ, Najjar S, Mitchell BD, Lawlor DA, Smith GD, Ben Shlomo Y, Andersen G, Borch-Johnsen K, Jorgensen T, Saramies J, Valle TT, Buchanan TA, Shuldiner AR, Lakatta E, Bergman RN, Uda M, Tuomilehto J, Pedersen O, Cao A, Groop L, Mohlke KL, Laakso M, Schlessinger D, Collins FS, Altshuler D, Abecasis GR, Boehnke M, Scuteri A \& Watanabe RM. Variations in the G6PC2/ABCB11 genomic region are associated with fasting glucose levels. Journal of Clinical Investigation 2008118 2620-2628. (doi:10.1172/JCI34566)

4 Bouatia-Naji N, Rocheleau G, Van Lommel L, Lemaire K, Schuit F, Cavalcanti-Proenca C, Marchand M, Hartikainen AL, Sovio U, De Graeve F, Rung J, Vaxillaire M, Tichet J, Marre M, Balkau B, Weill J, Elliott P, Jarvelin MR, Meyre D, Polychronakos C, Dina C, Sladek R \& Froguel P. A polymorphism within the G6PC2 gene is associated with fasting plasma glucose levels. Science $2008 \mathbf{3 2 0}$ 1085-1088. (doi:10.1126/science.1156849)

5 Bouatia-Naji N, Bonnefond A, Cavalcanti-Proenca C, Sparso T, Holmkvist J, Marchand M, Delplanque J, Lobbens S, Rocheleau G, Durand E, De Graeve F, Chevre JC, Borch-Johnsen K, Hartikainen AL, Ruokonen A, Tichet J, Marre M, Weill J, Heude B, Tauber M, Lemaire K, Schuit F, Elliott P, Jorgensen T, Charpentier G, Hadjadj S, Cauchi S, Vaxillaire M, Sladek R, 
Visvikis-Siest S, Balkau B, Levy-Marchal C, Pattou F, Meyre D, Blakemore AI, Jarvelin MR, Walley AJ, Hansen T, Dina C, Pedersen $\mathrm{O}$ \& Froguel P. A variant near MTNR1B is associated with increased fasting plasma glucose levels and type 2 diabetes risk. Nature Genetics 200941 89-94. (doi:10.1038/ng.277)

6 Prokopenko I, Langenberg C, Florez JC, Saxena R, Soranzo N, Thorleifsson G, Loos RJ, Manning AK, Jackson AU, Aulchenko Y, Potter SC, Erdos MR, Sanna S, Hottenga JJ, Wheeler E, Kaakinen M, Lyssenko V, Chen WM, Ahmadi K, Beckmann JS, Bergman RN, Bochud M, Bonnycastle LL, Buchanan TA, Cao A, Cervino A, Coin L, Collins FS, Crisponi L, de Geus EJ, Dehghan A, Deloukas P, Doney AS, Elliott P, Freimer N, Gateva V, Herder C, Hofman A, Hughes TE, Hunt S, Illig T, Inouye M, Isomaa B, Johnson T, Kong A, Krestyaninova M, Kuusisto J, Laakso M, Lim N, Lindblad U, Lindgren CM, McCann OT, Mohlke KL, Morris AD, Naitza S, Orru M, Palmer CN, Pouta A, Randall J, Rathmann W, Saramies J, Scheet P, Scott LJ, Scuteri A, Sharp S, Sijbrands E, Smit JH, Song K, Steinthorsdottir V, Stringham HM, Tuomi T, Tuomilehto J, Uitterlinden AG, Voight BF, Waterworth D, Wichmann HE, Willemsen G, Witteman JC, Yuan X, Zhao JH, Zeggini E, Schlessinger D, Sandhu M, Boomsma DI, Uda M, Spector TD, Penninx BW, Altshuler D, Vollenweider P, Jarvelin MR, Lakatta E, Waeber G, Fox CS, Peltonen L, Groop LC, Mooser V, Cupples LA, Thorsteinsdottir U, Boehnke M, Barroso I, Van Duijn C, Dupuis J, Watanabe RM, Stefansson K, McCarthy MI, Wareham NJ, Meigs JB \& Abecasis GR. Variants in MTNR1B influence fasting glucose levels. Nature Genetics 200941 77-81. (doi:10.1038/ng.290)

7 Lyssenko V, Nagorny CL, Erdos MR, Wierup N, Jonsson A, Spegel P, Bugliani M, Saxena R, Fex M, Pulizzi N, Isomaa B, Tuomi T, Nilsson P, Kuusisto J, Tuomilehto J, Boehnke M, Altshuler D, Sundler F, Eriksson JG, Jackson AU, Laakso M, Marchetti P, Watanabe RM, Mulder H \& Groop L. Common variant in MTNR1B associated with increased risk of type 2 diabetes and impaired early insulin secretion. Nature Genetics 200941 82-88. (doi:10.1038/ ng.288)

8 Kelliny C, Ekelund U, Andersen LB, Brage S, Loos RJ, Wareham NJ \& Langenberg C. Common genetic determinants of glucose homeostasis in healthy children: the European Youth Heart Study. Diabetes 200958 2939-2945. (doi:10.2337/db09-0374)

9 Tam CH, Ho JS, Wang Y, Lee HM, Lam VK, Germer S, Martin M, So WY, Ma RC, Chan JC \& Ng MC. Common polymorphisms in MTNR1B, G6PC2 and GCK are associated with increased fasting plasma glucose and impaired $\beta$-cell function in Chinese subjects. PLOS ONE 20105 e11428. (doi:10.1371/journal.pone.0011428)

10 Andersson EA, Holst B, Sparso T, Grarup N, Banasik K, Holmkvist J, Jorgensen T, Borch-Johnsen K, Egerod KL, Lauritzen T, Sorensen TI, Bonnefond A, Meyre D, Froguel P, Schwartz TW, Pedersen O \& Hansen T. The MTNR1B G24E variant associates with BMI and fasting plasma glucose in the general population in studies of 22,142 Europeans. Diabetes 201059 1539-1548. (doi:10.2337/db09-1757)

11 Reppert SM, Godson C, Mahle CD, Weaver DR, Slaugenhaupt SA \& Gusella JF. Molecular characterization of a second melatonin receptor expressed in human retina and brain: the Mel1b melatonin receptor. PNAS 199592 8734-8738. (doi:10.1073/ pnas.92.19.8734)

12 Ramracheya RD, Muller DS, Squires PE, Brereton H, Sugden D, Huang GC, Amiel SA, Jones PM \& Persaud SJ. Function and expression of melatonin receptors on human pancreatic islets. Journal of Pineal Research 200844 273-279. (doi:10.1111/j. 1600-079X.2007.00523.x)

13 Peschke E, Muhlbauer E, Musshoff U, Csernus VJ, Chankiewitz E \& Peschke D. Receptor (MT(1)) mediated influence of melatonin on cAMP concentration and insulin secretion of rat insulinoma cells INS-1. Journal of Pineal Research 200233 63-71. (doi:10.1034/j. 1600-079X.2002.02919.x)

14 Peschke E, Bach AG \& Muhlbauer E. Parallel signaling pathways of melatonin in the pancreatic $\beta$-cell. Journal of Pineal Research 2006 40 184-191. (doi:10.1111/j.1600-079X.2005.00297.x)
15 Peschke E, Stumpf I, Bazwinsky I, Litvak L, Dralle H \& Muhlbauer E. Melatonin and type 2 diabetes - a possible link? Journal of Pineal Research 200742 350-358. (doi:10.1111/j. 1600-079X.2007.00426.x)

16 Mulder H, Nagorny CL, Lyssenko V \& Groop L. Melatonin receptors in pancreatic islets: good morning to a novel type 2 diabetes gene. Diabetologia 200952 1240-1249. (doi:10.1007/s00125-0091359-y)

17 Kromeyer-Hauschild K, Wabitsch M, Geller F, Ziegler A, Geiß HC, Hesse V, Hippel A, Jaeger U, Johnsen D, Kiess W, Korte W, Kunze D, Menner K, Müller M, Niemann-Pilatus A, Remer T, Schaefer F, Wittchen HU, Zabransky S, Zellner K \& Hebebrand J. Perzentile für den body mass index für das Kindes- und Jugendalter unter Heranziehung verschiedener deutscher Stichproben. Monatsschrift für Kinderheilkunde $2001 \quad \mathbf{1 4 9} \quad 807-818 . \quad$ (doi:10.1007/ s001120170107)

18 Cole TJ. The LMS method for constructing normalized growth standards. European Journal of Clinical Nutrition 199044 45-60.

19 Matthews DR, Hosker JP, Rudenski AS, Naylor BA, Treacher DF \& Turner RC. Homeostasis model assessment: insulin resistance and $\beta$-cell function from fasting plasma glucose and insulin concentrations in man. Diabetologia 198528 412-419. (doi:10.1007/ BF00280883)

20 Gungor N, Saad R, Janosky J \& Arslanian S. Validation of surrogate estimates of insulin sensitivity and insulin secretion in children and adolescents. Journal of Nutrition 2004 144 47-55. (doi:10. 1016/j.jpeds.2003.09.045)

21 Ingelsson E, Langenberg C, Hivert MF, Prokopenko I, Lyssenko V, Dupuis J, Magi R, Sharp S, Jackson AU, Assimes TL, Shrader P, Knowles JW, Zethelius B, Abbasi FA, Bergman RN, Bergmann A, Berne C, Boehnke M, Bonnycastle LL, Bornstein SR, Buchanan TA, Bumpstead SJ, Bottcher Y, Chines P, Collins FS, Cooper CC, Dennison EM, Erdos MR, Ferrannini E, Fox CS, Graessler J, Hao K, Isomaa B, Jameson KA, Kovacs $\mathrm{P}$, Kuusisto J, Laakso M, Ladenvall C, Mohlke KL, Morken MA, Narisu N, Nathan DM, Pascoe L, Payne F, Petrie JR, Sayer AA, Schwarz PE, Scott LJ, Stringham HM, Stumvoll M, Swift AJ, Syvanen AC, Tuomi T, Tuomilehto J, Tonjes A, Valle TT, Williams GH, Lind L, Barroso I, Quertermous T, Walker M, Wareham NJ, Meigs JB, McCarthy MI, Groop L, Watanabe RM \& Florez JC. Detailed physiologic characterization reveals diverse mechanisms for novel genetic Loci regulating glucose and insulin metabolism in humans. Diabetes 201059 1266-1275. (doi:10.2337/db09-1568)

22 Scherag A, Dina C, Hinney A, Vatin V, Scherag S, Vogel CI, Muller TD, Grallert H, Wichmann HE, Balkau B, Heude B, Jarvelin MR, Hartikainen AL, Levy-Marchal C, Weill J, Delplanque J, Korner A, Kiess W, Kovacs P, Rayner NW, Prokopenko I, McCarthy MI, Schafer H, Jarick I, Boeing H, Fisher E, Reinehr T, Heinrich J, Rzehak P, Berdel D, Borte M, Biebermann H, Krude H, Rosskopf D, Rimmbach C, Rief W, Fromme T, Klingenspor M, Schurmann A, Schulz N, Nothen MM, Muhleisen TW, Erbel R, Jockel KH, Moebus S, Boes T, Illig T, Froguel P, Hebebrand J \& Meyre D. Two new Loci for body-weight regulation identified in a joint analysis of genome-wide association studies for early-onset extreme obesity in French and German study groups. PLoS Genetics 20106 e1000916. (doi:10. 1371/journal.pgen.1000916)

23 Lindgren CM, Heid IM, Randall JC, Lamina C, Steinthorsdottir V, Qi L, Speliotes EK, Thorleifsson G, Willer CJ, Herrera BM, Jackson AU, Lim N, Scheet P, Soranzo N, Amin N, Aulchenko YS, Chambers JC, Drong A, Luan J, Lyon HN, Rivadeneira F, Sanna S, Timpson NJ, Zillikens MC, Zhao JH, Almgren P, Bandinelli S, Bennett AJ, Bergman RN, Bonnycastle LL, Bumpstead SJ, Chanock SJ, Cherkas L, Chines P, Coin L, Cooper C, Crawford G, Doering A, Dominiczak A, Doney AS, Ebrahim S, Elliott P, Erdos MR, Estrada K, Ferrucci L, Fischer G, Forouhi NG, Gieger C, Grallert H, Groves CJ, Grundy S, Guiducci C, Hadley D, Hamsten A, Havulinna AS, Hofman A, Holle R, Holloway JW, Illig T, Isomaa B, Jacobs LC, Jameson K, Jousilahti P, Karpe F, Kuusisto J, Laitinen J, Lathrop GM, Lawlor DA, Mangino M, McArdle WL, Meitinger T, Morken MA, Morris AP, Munroe P, Narisu N, Nordstrom A, Nordstrom P, Oostra BA, Palmer CN, 
Payne F, Peden JF, Prokopenko I, Renstrom F, Ruokonen A, Salomaa V, Sandhu MS, Scott LJ, Scuteri A, Silander K, Song K, Yuan X, Stringham HM, Swift AJ, Tuomi T, Uda M, Vollenweider P, Waeber G, Wallace C, Walters GB, Weedon MN, Witteman JC, Zhang C, Zhang W, Caulfield MJ, Collins FS, Davey SG, Day IN, Franks PW, Hattersley AT, Hu FB, Jarvelin MR, Kong A, Kooner JS, Laakso M, Lakatta E, Mooser V, Morris AD, Peltonen L, Samani NJ, Spector TD, Strachan DP, Tanaka T, Tuomilehto J, Uitterlinden AG, Van Duijn CM, Wareham NJ, Hugh W, Waterworth DM, Boehnke M, Deloukas P, Groop L, Hunter DJ, Thorsteinsdottir U,
Schlessinger D, Wichmann HE, Frayling TM, Abecasis GR, Hirschhorn JN, Loos RJ, Stefansson K, Mohlke KL, Barroso I \& McCarthy MI. Genome-wide association scan meta-analysis identifies three Loci influencing adiposity and fat distribution. PLoS Genetics 20095 e1000508. (doi:10.1371/journal.pgen. 1000508)

Received 23 September 2010

Accepted 8 November 2010 